by Elena Druguet ${ }^{1, \#}$, Cees W. Passchier ${ }^{2, \#}$, Giorgio Pennacchioni ${ }^{3, \#}$, Jordi Carreras ${ }^{1}$

\title{
Geoethical education: A critical issue for
} geoconservation

\author{
${ }^{1}$ Departament de Geologia, Universitat Autònoma de Barcelona, 08193 Bellaterra, Spain. E-mail: elena.druguet@uab.cat \\ 2 Department of Earth Sciences, University of Mainz, 55099 Mainz, Germany \\ ${ }^{3}$ Dipartimento di Geoscienze, University of Padova, I-35131 Padova, Italy \\ \# TecTask (IUGS)
}

Some geological outcrops have a special scientific or educational value, represent a geological type locality and/or have a considerable aesthetical/photographic value. Such important outcrops require appropriate management to safeguard them from potentially damaging and destructive activities. Damage done to such rock exposures can include drill sampling by geologist for scientific purposes. In this work, we show how outcrops important to structural geology and petrology can be damaged unnecessarily by drill coring. Unfortunately, regulation and protection mechanisms and codes of conduct can be ineffective. The many resources of geological information available to the geoscientist community, e.g. via Internet, promote access to sites of geological interest, but can also have a negative effect on their conservation. Geoethical education on rock sampling is therefore critical for conservation of the geological heritage. Geoethical principles and educational actions are aimed to be promoted at different levels to improve geological sciences development and to enhance conservation of important geological sites.

\section{Conserving the geological record}

Geological Heritage represents a collection of records of Earth's history and processes. Rock exposures are the most important information sources to provide evidence for deciphering the complex evolution of the Earth. Some outcrops are crucial to interpret the geological evolution of a region, others are important for understanding aspects of petrological, tectonic or geomorphologic processes. Occasionally, geologists encounter outcrops which immediately stand out because they are exceptionally clear examples of certain features, text-book examples of certain mechanism or simply structures of a beauty (Fig. 1). Other important outcrops are those where a particular formation or structure has been first described, which become type localities for such features. Such outcrops are of great value for teaching and geotourism, and some have been known for generations and are being visited time and again.

The value and significance of the geological heritage merits appropriate management to safeguard it and, if particularly vulnerable, preservation for education, research and enjoyment of present and future generations. Many geological sites are permanently threatened, even if they are included in protected sites (e.g. Carreras and Druguet, 2000; Reimold et al., 2006). This can be due to the fact that rocks are to many people a fixed, unnoticed and uninteresting background to the biosphere, for which protection measures are irrelevant. Conservation regulation and management plans are often primarily based on biodiversity and ecological criteria, causing a lack of effective tools to take actions to prevent destruction of geological heritage. Over the last two decades, great efforts have been made to promote the recognition of the geological heritage as an important part of natural and cultural heritage. However, when examining current protection plans and nature conservation policies, limitations of their efficacy in geoconservation become evident. For instance, this problem can be detected in the framework given by the International Union for Conservation of Nature (IUCN). The IUCN has established several categories of protected areas which have significance for setting management plans (Dudley, 2008), and these are based on principles that are systematically biased towards biodiversity aspects. It is important to notice that the IUCN is the advisory body for natural heritage nominations to the UNESCO World Heritage List (http:// whc.unesco.org/en/guidelines). Specifically targeted for geoheritage is the Global Geoparks Network, a UNESCO supported initiative which aims to stimulate sustainable economic and cultural development of a region based on the presence of significant geological sites (http://www.globalgeopark.org/, Global Geoparks Network, 2010). However, only geosites that are large enough to serve local/regional economic and cultural development can be included in this category. Nevertheless, integrated conservation and management plans seem to represent an adequate strategy to protect the rather common sites where geological heritage is associated with other natural and/or cultural values. In this context, geoconservation, as a sum of strategies related to the assessment and conservation of the geological heritage, must serve to strengthen the implementation of geological criteria in these integrated management plans. However, highly significant and valuable geological sites do not need to be included in protected areas to deserve conservation.

\section{Outcrop damage undertaken in the name of scientific advancement}

Outcrops are being threatened in several ways. Outcrops all 

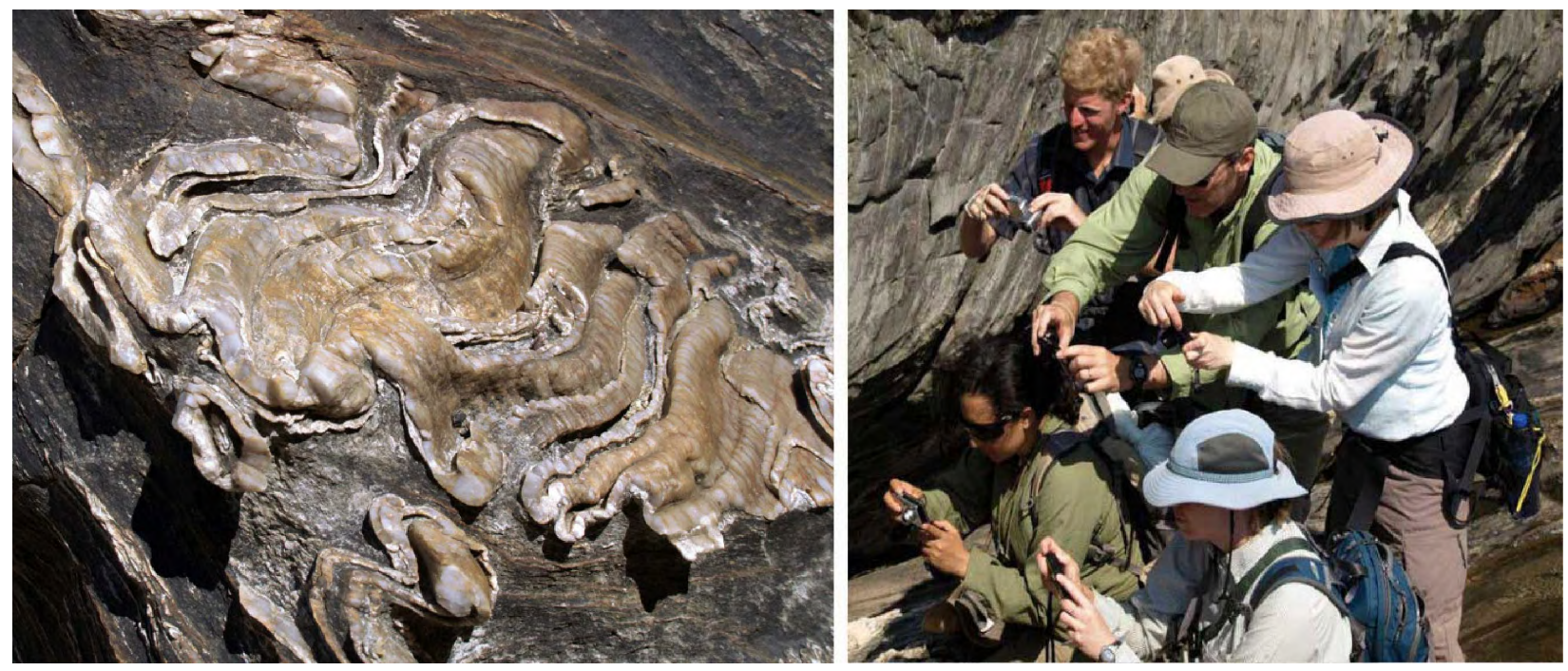

Figure 1. Example of an intact outstanding outcrop of refolded folds from the classical Cap de Creus shear zones (Eastern Pyrenees, Spain), and the reaction of a group of enthusiastic geologists during the 2011 GSA Penrose Conference "Deformation Localization in Rocks: New Advances", taking photographs of the outcrop.

gradually weather and erode, and are constantly being destroyed (and created) by road building or construction work. Depending on climate and geological environment, outcrop surfaces remain visible for decades to several thousands of years. This damage by erosion and human construction activity is similar to that experienced by archaeological sites and historical buildings. In some cases, damage, partial loss and destruction cannot be avoided, but generally, less care is taken in protecting geological outcrops than in preserving archaeological sites. For example, in Europe, the 1992 Valetta Treaty forces states to protect their archaeological heritage and to take care that sites are protected or, where this is not possible, properly investigated and recorded (http://conventions.coe.int/Treaty/EN/ Reports/Html/143.htm). ICOMOS (International Council on Monuments and Sites) and UNESCO have similar initiatives, such as the "Recommendation on International Principles Applicable to Archaeological Excavations" (UNESCO, 1956). Archaeological sites are commonly discovered during construction work, and in such cases, there is often immediate action to try and protect the site. This is much less common with geological sites, with very few examples of outcrop protection during road building (e.g. Van Hise Rock National Historic Landmark, Wisconsin, USA, http://www.nps.gov/nhl/).

Outcrops are not only threatened by building or similar largescale destructive activities. On a smaller scale, fossil and mineral rich sites can be damaged by collectors and merchants who collect fossils and minerals for private or commercial purposes (Kiernan, 1997; Sharples, 2002; van Loon, 2008). Outcrops seem to be unique in that they may become the object of damage or destruction motivated by research aims. The extreme clearness and scientific value of some outcrops is tempting geologists, as scientists, to use them for research, and this means sampling. This commonly brings researchers into the moral dilemma that they would like to sample a structure for lab work, but in doing so, the outcrop may be damaged to such an extend that its aesthetic appeal and scientific value are diminished or destroyed. In archaeology and art, preservation of the artefact or artwork is always more important than invasive research that could damage it, and a large number of non-destructive research techniques have been developed. Few people would consider taking a rock sample from the Taj Mahal or the Acropolis of Athens. In geology, we are less used to the idea to protect outstanding outcrops in a similar way as artefacts. The geological community should be more aware of conservation issues and try to conserve exceptional outcrops so that future research work and educational use can continue.

Hammering and drill coring are the two most common techniques used by geologists for rock sampling. With the availability of portable drilling equipments, rock coring has progressively gained popularity over the last decades over traditional methods: coring allows samples to be taken precisely at specific positions of interest from an outcrop pertinent to the geological research being undertaken, especially on smooth surfaces that are hard to sample by hammering. Coring however, although apparently cleaner and less destructive than hammering, can cause much more damage to the outcrops if undertaken irresponsibly. This is because, as explained by MacFadyen (2010), irresponsible coring can deface or even ruin the appearance and photographic value of outcrops. Small-scale geological features may even be completely destroyed by coring. Hammering can also damage outcrops, especially if the interesting structure is completely removed, but otherwise leaves behind a more natural scar which resembles the pattern of fractures and joints that normally constitutes the face of an outcrop: it may blend imperceptibly with the outcrop after a number of years because of weathering. Drill hole scars are much more permanent. Saw sampling is another procedure that can be very adverse to delicate outcrops, but saw cuts can be more easily restored to a natural looking scar by hammering.

In the UK, a country where geoconservation was pioneered and it is now well established, the "Geologist's Association" of the Geological Society of London published in 1989 the "Code of Conduct for Rock Coring" (Robinson, 1989a,b). Despite the existence of this code, irresponsible coring continues to this day in the UK, as reported by Campbell and Wood (2002) and MacFadyen (2006). Increasing concern and awareness of this problem resulted into several publications by MacFadyen (2007, 2010), where particularly destructive cases of coring in the UK are communicated. This resulted in the preparation of the Scottish Core Code by the Scottish Natural Heritage (MacFadyen, 2011) and to the 2011 updating of the former "Code of Conduct for Rock Coring" by the "Geologist's Association" (www.geologistsassociation.org.uk). 
Irresponsible sampling is a recognised problem throughout the world. It is common in many countries that scientific and professional geological associations have a code of conduct or ethical behaviour that sets out recommendations and the procedures to be taken into account. However, apart from the above reported documents by the Scottish Natural Heritage and the Geologists' Association in the UK, there is no record of any other national or international document aimed as an ethic protocol or code of conduct specific to rock sampling for the conservation of relevant outcrops. A step in this direction has been taken by the Spanish Association of Geologists (http:// www.icog.es/) on its recently updated Deontological Code, through a statement concerning the need for compatibility between geological activities and geoheritage. Besides this, the Geological Society of South Africa recommends the use of the "Code of Conduct for Rock Coring" produced by the UK Geologists' Association.

In order to illustrate the serious damage scientific sampling can do, we give some examples of outcrops important to structural geology and petrology where sampling was undertaken by means of drilling methods, and any protective measures taken (Figs. 2 to 6). They are all relatively small (metre to centimetre scale) outcrops or parts of outcrops that contain delicate structures. After the rock coring actions, the aesthetic and photographic value of these outcrops has decreased considerably.

\section{Laghetti and Ponte Brolla areas, Maggia nappe, Swiss Alps}

These are among the most classic and internationally well-known outcrop areas for ductile shear zones. The spectacular shear zones exposed in the Laghetti area (see Fig. 2a, b) were first described by Kerrich et al. (1977), Ramsay and Allison (1979), Ramsay (1980) and Simpson $(1981,1983)$. Some of the earliest geometric models of shear zones and of quantitative strain estimates were performed using these shear zones as an example. These classic shear zones appear substantially damaged (Fig. 2b) and also a mafic dyke from the same locality has been aggressively drilled (Fig. 2c).

At Ponte Brolla, another delicate outcrop shows melt-filled mesoscale shear bands in migmatitic gneiss of the Insubric mylonite zone (Fig. 3). This is one of the best examples in Europe of high-grade shear zones coeval with anatexis (see Merle et al., 1989; Passchier, 2001; Passchier and Coelho, 2006; and Berger et al., 2008, for further details). The outcrop, which consist of no more that 10-15 well exposed shear bands, is visited by numerous student groups from German and
Swiss universities. Defacing of the outcrop took place despite Ponte Brolla-Losone being catalogued since 1977 in the Swiss Federal Inventory of Landscapes and Natural Monuments (http:// www.bafu.admin.ch/) which aims to protect landscapes of national importance. In contrast to landscape and bioecological elements, geological heritage is not yet sufficiently integrated into local and national Swiss management plans, so that, according to the Swiss Working Group Geotope of the Swiss Academy of Sciences, the capacity to implement restriction and protection activities on geological heritage sites is still very limited (Stürm, 2005). The Group Geotope started in 2006 an inventory of geosites to promote geoconservation in Switzerland, but currently lacks legal status. The last revision of this inventory (Berger et al., 2011) embraces Ponte Brolla outcrops (geosite \#499: Gole di Ponte Brolla), but not yet the Laghetti area.

\section{Mosel valley, Rhenish massif, Germany}

This is an exclusive example of cleavage refraction in Devonian slates and sandstones (Fig. 4). Early tectonic quartz veins developed in sandstone layers follow the refractive cleavage and highlight the structure. The outcrop is a classical site visited by many student groups from Germany and Holland. The drill holes shown here were made at the end of the 1980's. In this particular case, we know that the samples were taken for a comparative study of the magnetic properties of sandstone and slate, where any other less spectacular outcrop would have served equally well. In fact, the samples were never used since other, better examples were found later.
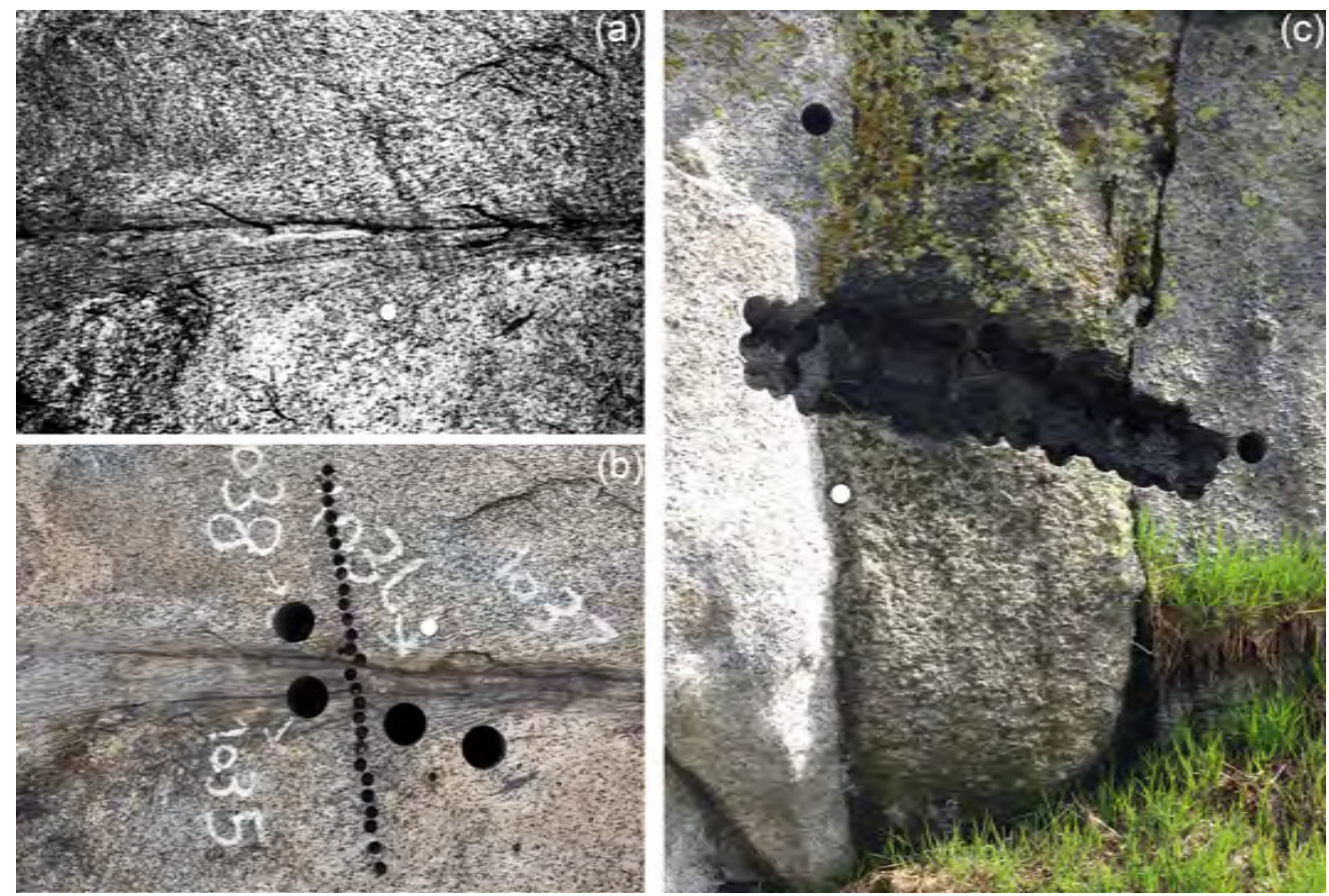

Figure 2. Two examples of destruction by drill coring in the Laghetti area, Swiss Alps. (a) Ductile shear zone in granodiorite, photograph corresponding to Fig. 10a of Ramsay (1980), prior to rock sampling. A sigmoidal schistosity fabric is well developed around the shear zone. Reprinted from Journal of Structural Geology, 2, Ramsay, J.G., Shear zone geometry: a review, 83-99, Copyright (1980), with permission from Elsevier. (b) The same outcrop photographed in 2010. Notice from the graffitied numbers that the four large holes are older than the small ones, which may indicate either two different projects or a repeated sampling campaign. (c) A giant gap made of overlapping core holes to a lamprophyre dyke intruded in granodiorite a few tens of meters from (b), also photographed in 2010. 


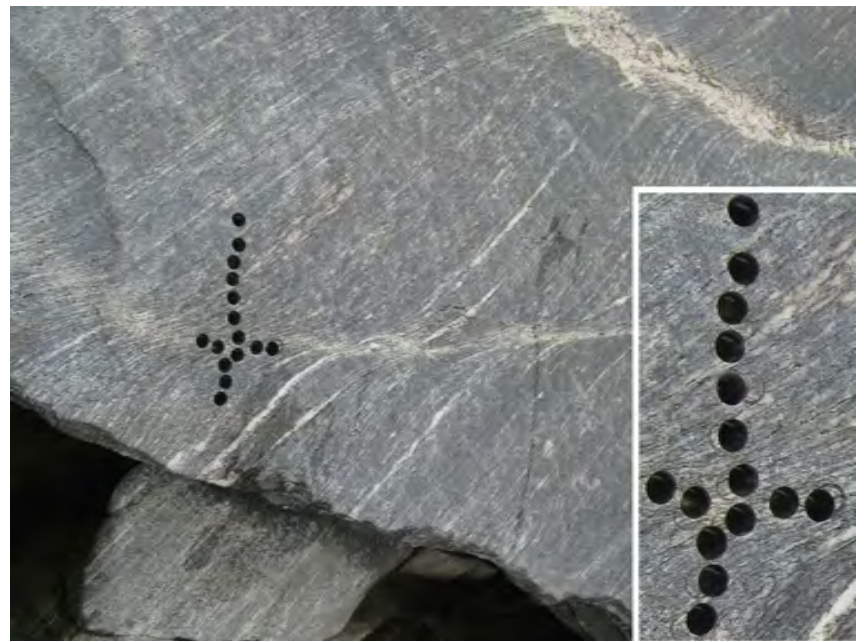

Figure 3. Small outcrop in the Ponte Brolla area (Ticino, Switzerland) showing superb examples of migmatitic gneisses with shear zones filled with melt. The cross-shaped drill coring has destroyed the photogenic interest of the structures and irreversibly removed part of the information that was recorded in these migmatitic rocks.

\section{Aiguablava, Costa Brava, Catalan coastal batholith in NE Spain}

The lamphrophyric dyke swarm of Aiguablava configures a site of great scientific and educational value in the fields of igneous petrology and tectonics, located in an outstanding coastal landscape of almost equally magnificent geomorphological value. Dyke emplacement is controlled by the presence of a widespread network of joints developed during cooling of the late Variscan granitic host rocks (Gimeno, 2002; Passchier, 2007; Enrique, 2009; Martínez-Poza et al., 2012). Sa Planassa has become a classic locality to see the dyke cross-cutting relationships and also the intrusive structures associated to different joint sets. Geology professors with students from various Spanish universities and from secondary schools have been regularly visiting this locality for more than forty years, and visits continue nowadays in the presence of defacing coring holes (Fig. 5). In 2009, the most magnificent dyke locality at Sa Planassa (Fig. 5) was marred with numerous drilling holes. It is an unfortunate example of how geological heritage can be destroyed by geologists for scientific interest, while there are nearby other, less conspicuous outcrops where identical samples of these lamphrophyres can be taken. This happened despite Aiguablava being catalogued in the "Inventory of sites of geological interest of Catalunya" (Geozone 354: Aiguablava and Aigua-Xelida dyke swarm, Carreras and Gimeno, 2000) and it being protected by the Catalan legislation for its natural value, as it belongs since 1992 to the "Special plan for protecting the natural environment and landscape" (PEIN “Muntanyes de Begur”). In 2010, after the Aiguablava outcrops had been damaged, the Catalan legislation approved a new plan which regulates the use of the PEIN "Muntanyes de Begur" site for geological site protection.

\section{Bear Creek area, John Muir Wilderness, Sierra Nevada, USA}

This spectacular area has hosted numerous detailed studies on post-magmatic deformation of granitoids including the development of ductile shear zone and faults (Segall and Simpson, 1986; Segall and Pollard, 1983; Martel et al., 1988; Pennacchioni and Zucchi, in press). This reflects, in part, the extent of extensive spectacular exposures in glaciated outcrops. The damaged outcrops (Fig. 6) show foliated contractional jogs at the tips of extremely localized sinistral ductile shear zones nucleated on precursor en echelon joints which developed during post-magmatic cooling.

In the U.S. Wilderness areas, urban development is prohibited by law and thus land has to be administered to preserve its wilderness character. The John Muir Wilderness area belongs to the Inyo and Sierra National Forests, established in 1964 by the United States Forest Service. The specific regulation states that a notice of intent and a permit are required for rock sampling, with request to cover the holes before leaving the site. Some of the drill holes in this area have indeed been filled in with concrete by those who carried out the coring under
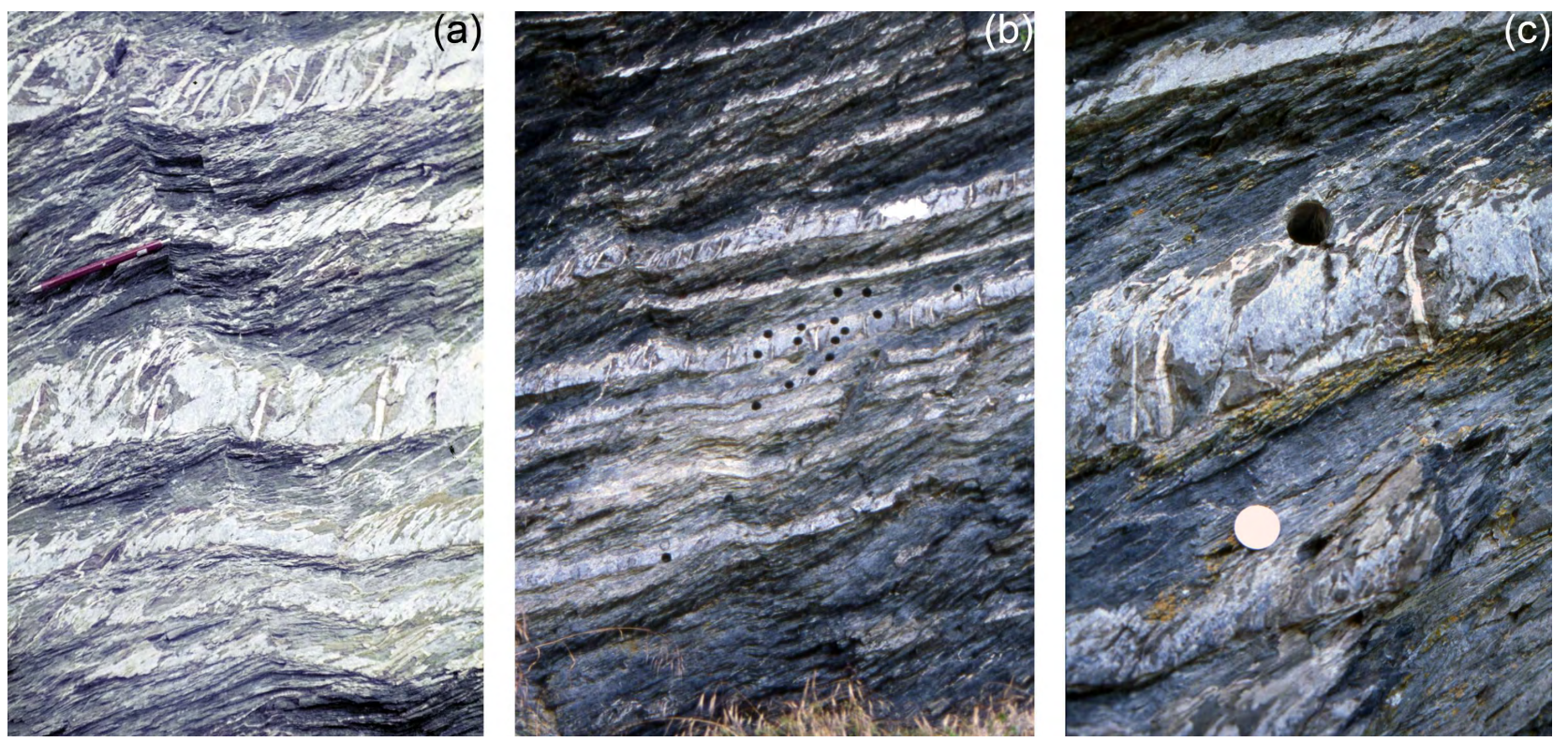

Figure 4. Outcrop from the Mosel valley (Germany) showing excellent examples of cleavage and vein refraction structures. (a) The outcrop in 1971. Pencil for scale. (b) The outcrop in 1999 after devastating drill coring. (c) Detail of (b). 

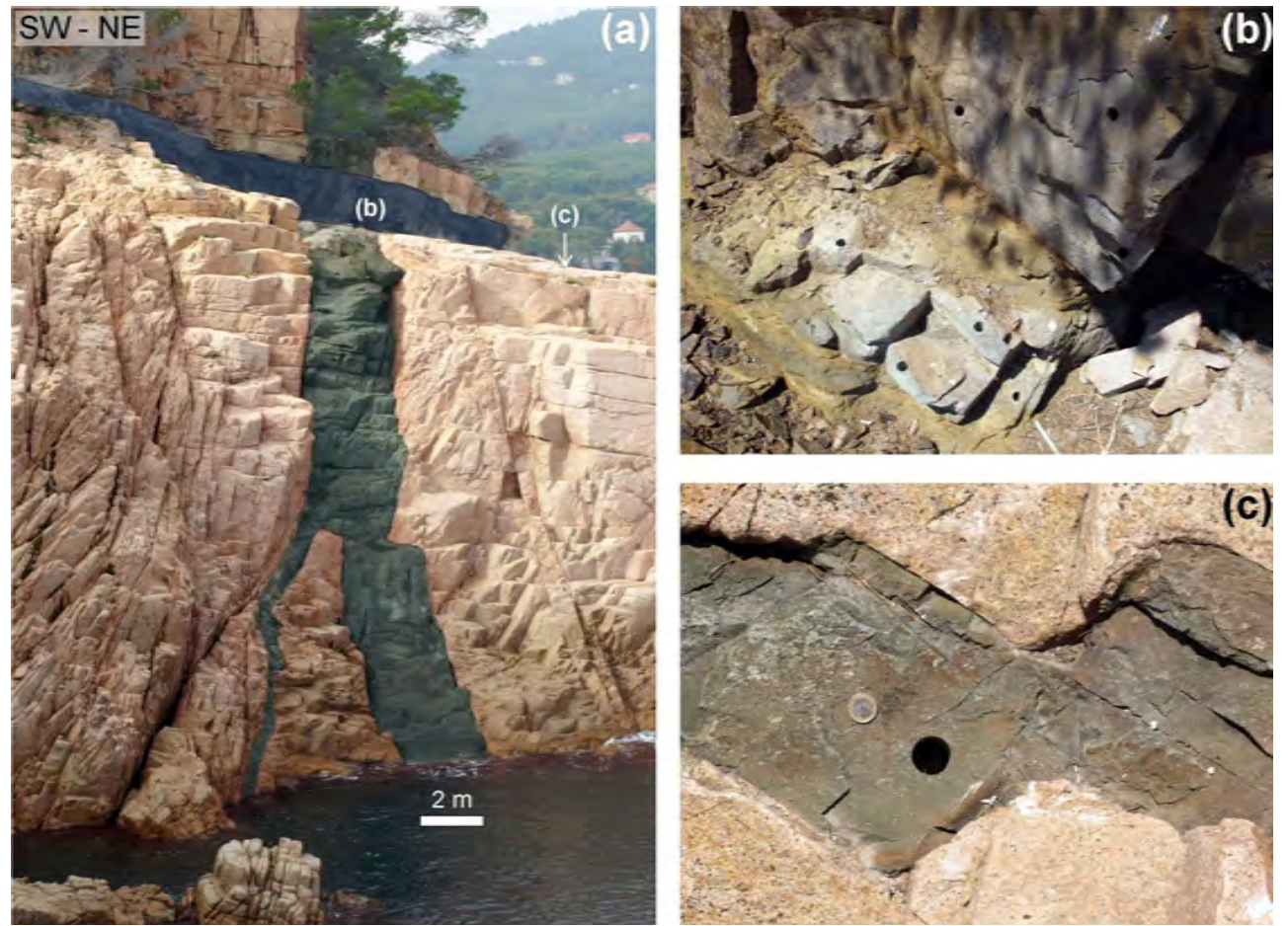

are scientifically very useful to the geoscientist community and have actually become one of the most effective media to promote geoconservation and geotourism.

A number of activities have been started in recent years to provide information of relevant geological sites through the indication of the precise outcrop position, easily recorded and located with any modern GPS device. Examples of these initiatives are the

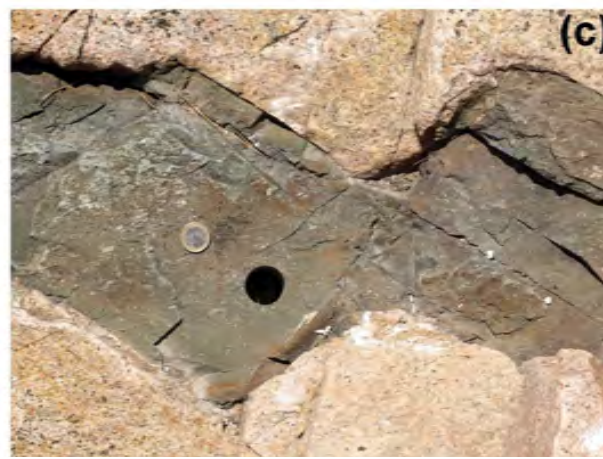

(c) DIoGeneS "database of Digital Images of Geologic \& nice Structures" (http://www.diogenes.ethz.ch/) and the interactive outcrop database Outcropedia of TecTask (www.outcropedia.org/). It is also increasingly common in scientific papers, guides and divulgation pamphlets to indicate the GPS coordinates of the published figures and spots of interest: this trend should be encouraged and recommended. KML (Keyhole Markup Language), which can be used for expressing geographic annotation and visualization within Internet-based Earth browsers, is now accepted by photographs of the damage done to dykes.

a permit, although the effect is unsatisfactory as the outcrops have not recovered their original state (compare Figs. $6 a$ and $b$ ).

\section{Komati River gorges, Songimvelo Nature Reserve, South Africa}

Reimold et al. (2004, 2006) reported damage to many prime exposures along the Komati River gorge in the Songimvelo Nature Reserve, where some of the earliest and most interesting rocks on Earth are found. These were defaced by core sampling for scientific purposes under permission of the Park board (de Wit, 2005). After much discussion among the geological community, the results of this sampling were published in Biggin et al. (2011).

\section{Bartlett Wash, Utah, USA}

Recently, another example of damage to an important outcrop was reported by Dr. Bruce Trudgill (Colorado School of Mines) on several internet sites (e.g. http://www.structuralgeology.org/2012/04/ geo-vandalism-in-bartlett-wash-utah.html). The defaced exposure, in the Bartlett Wash area near Moab, belongs to an area which is famous for its well-exposed deformation bands in sandstone (e.g. Davatzes et al., 2005; Fossen, 2010, his figure 8.11). Sampling was performed in this case by geoscientists using an electric rock saw.

\section{Networks of information and communi- cation technology: positive and negative side effects}

The numerous geological resources now available via Internet scientific journals and can become a routine procedure to georeference outcrops. This will allow anybody to access and enjoy the most spectacular geosites. However, it also exposes the same sites to the risk of irresponsible sampling. It is therefore recommended that databases and promotional activities are accompanied by guidance notes of good sampling practice to decrease the risk of damage to outcrops, and to avoid that these new initiatives become frustrated by a dwindling number of scientist who wish to publish the location of spectacular outcrops.

\section{Call for geoethical education strategies}

Geoconservation should be a fundamental practice of science and of scientific deontological behaviour. Though sampling, and more specifically coring, is useful and often critical to conduct laboratory analysis and for scientific achievements, it should in most cases be possible to target outcrops where this kind of action has no relevant impact, therefore allowing the best, or unique examples of spectacular geological structures to be protected for future research and educational goals.

It follows that geoethical education is a key issue for geoconservation. Geoethics is an interdisciplinary approach between geosciences and ethics whose main concerns are sustainable development and use of geological resources, appropriate management of natural hazards, geoscience communication and legal aspects, museology and also geoheritage and planetary protection. This concept, first defined by Martínez-Frías (2008) has ben further reviewed and developed by Martínez-Frías (2011), Ferrero et al. (2012) and Peppoloni and Di Capua (2012), among others. The 2011 "International Declaration on Geoethics" states among its recommendations the need to strengthen the links of geoethics with 

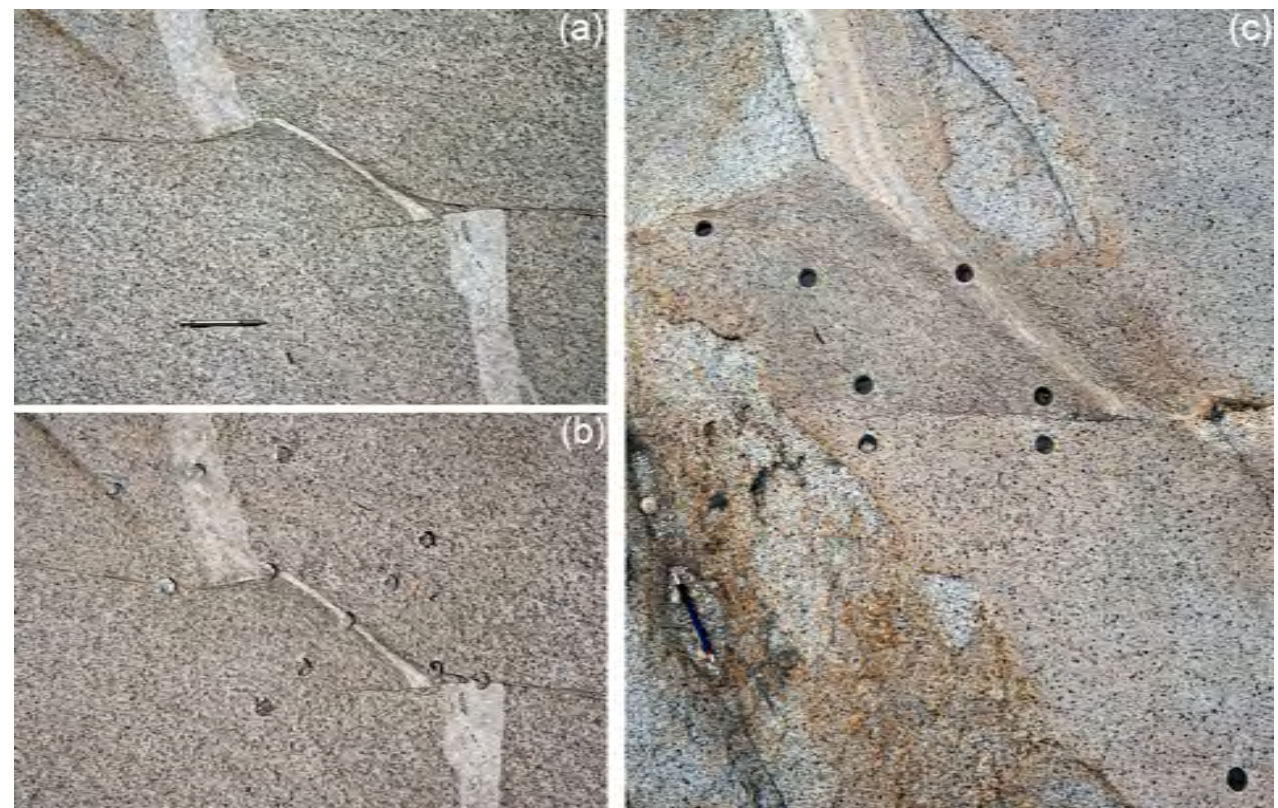

Figure 6. Photographs of spectacular outcrops located in the East Fork of Bear Creek and in the Hilgard Branch within the John Muir Wilderness, Sierra Nevada, USA, where sampling should be particularly careful. (a) Outcrop showing the displacement and thinning of a leucocratic dyke across shear zones and a contractional jog. This figure shows as the outcrop appeared in 2007. (b) The same outcrop as it is now (photograph taken summer 2011). Most of the drill holes in this area have been restored with a concrete filling, in order to somehow repair the visual impact of coring, as is enforced by restrictive sampling permits. However, this is a clear example of how restoration cannot return an outcrop its original beauty and a clear example of an outcrop where drilling or sampling should have been avoided. (c) Another outcrop, from the Hilgard Branch, damaged by drilling.
We would like to give this tentative outline requesting responsible behaviour, guided and inspired by the UK Geologists's Association "Code of Conduct for Rock Coring":

- Drill sampling is particularly threatening because it has a negative visual impact, whilst many times unnecessary. Before sampling, geologists should think about the question "is drill sampling necessary for the study being carried on?"

- Do not take samples from the centre of a geological type locality or a site of especial scientific, didactic interest or aesthetical/photographic value. If an outcrop is spectacular enough that deserves being photographed, then you should not core or sample the rock face that has been recorded. The same applies to outstanding outcrops stored in websites like the "Outcropedia".

- Sample other parts of the same or a neighbouring outcrop where there is less impact. Core samples must be discrete in location; take cores from the least exposed faces and try to plug the holes using the outer end of the core, if possible.

- Before sampling ask experts and authorities (e.g. Natural Reserve or National Park managers if the area is protected) for advise and permission.

geethics into any activity related with abiotic world. This has recently been proclaimed by the "Working Group for Geoethics" of the AGID (Association of Geoscientists for International Development) and the newly established International Association for Geoethics. However, geoconservation concerns are more implicit than explicit in these publications. More clear and explicit is the recently updated Deontological Code of the Spanish Association of Geologists (http:/ /www.icog.es/), which includes a paragraph requesting geologists to be aware of geological heritage while performing their activities on rock exposures.

All these actions should explicitly recognise geological heritage outcrops and call for their conservation. The geosciences community should apply similar principles to geological outcrops as those applied by most historians and archaeologists to the study of ancient monuments or archaeological sites. Such principles are communicated through protocols, codes, best practices, regulations and policies that provide national and international frameworks for heritage protection. In the case of archaeological heritage it is worth to notice the prompt edition of its international protection principles (UNESCO, 1956).

We consider that guides and codes of ethical conduct should incorporate guidelines for rock sampling, and outcrop conservation, such as done by different associations in the UK (referred to in a previous section). Concerning mitigation of damaged outcrops, some guidelines are given and research is being done in Europe by the Scottish Natural Heritage to establish a methodology for outcrop restoration (see MacFadyen, 2011). It would be useful to expand this initiative to investigate what measures can be taken to restore drillcoring damage to outcrops.

\section{Final remarks}

Geoethics, geo-education and geoconservation are intrinsically related principles that are to become integrated for the best practice in geosciences. Geoconservation and geoscientific sampling can be reconciled if we place geoconservation principles before individual research aims. Sampling is not antithetical to geoconservation when done in an appropriate and careful way. Also in geological sciences, it is not just what we do, but how we do it that matters.

Regulations, although necessary, can prove to be difficult to implement and are sometimes ineffective. Therefore, geoethical education on rock sampling seems to be a critical issue for conservation of our geological heritage.

Geoethical principles are aimed to be promoted at different levels:

- Ethical protocols and codes of conduct should include geoconservation issues, being explicit about responsible sampling. This could be included into existing and/or newly designed procedures and standards of different institutions: education and research centres, publishing companies, funding agencies and national or international associations. In this sense, it would also be useful to join and coordinate efforts that are being made by several IUGS commissions and groups on specific aspects that may be directly or indirectly related to geoconservation, such as the TecTask Commission on Tectonics and Structural Geology (to which the authors of this paper belong), the Geoheritage Task 
Group (GTG), the Commission on Geoscience Education, Training and Technology Transfer (COGE) and the Initiative on Forensic Geology (IFG).

- Geoscience teachers and supervisors should advise their students of the existing codes and have a general responsibility to teach their students the aesthetic and scientific value of exceptional outcrops, and responsible sampling techniques.

- It is important to promote the principles of geoconservation among landholders, authorities and managers of entities in charge of the protected sites and responsible for the permits. However, we cannot delegate all responsibility to land managers who are often not acquainted with the importance of these outcrops, and can hardly discriminate between common and exceptional rocky outcrops. Geoconservation will only be achieved through effectively coordinated links between responsible field geologists and institutions.

- The promotional activities through information technologies referred to in a previous section, could be complemented with a warning message referred to rock sampling and other geoethical indications.

We trust that these actions will help to improve geological sciences in all their aspects, and will enhance conservation of important geological features (regardless if they are in protected areas or not) for future generations to learn and enjoy.

\section{Acknowledgements}

We thank our colleagues from Tectask for their concern on this issue, and to Pere Enrique for his guidance in the Aiguablava case. The authors are also particularly grateful to Colin MacFadyen and an anonymous reviewer for very constructive reviews that have greatly improved the paper.

\section{References}

Berger, A., Burri, T., Alt-Epping, P., and Engi, M., 2008, Tectonically controlled fluid flow and water-assisted melting in the middle crust: An example from the Central Alps: Lithos, v. 102, pp. 598-615.

Berger, J.P., Reynard, E., Constandache, M., Felber, M., Häuselmann, Ph., Jeannin, P-Y., and Martin, S., 2011, Révision de l'inventaire des géotopes suisses: rapport du groupe de travail 2008-2011: Groupe de travail pour les géotopes en Suisse, Fribourg, sc/nat+ Geosciences, Platform of the Swiss Academy of Sciences.

Biggin, A.J., de Wit, M.J., Langereis, C.G., Zegers, T.E., Voute, S., Dekkers, M.J., and Drost, K., 2011, Palaeomagnetism of Archaean rocks of the Onverwacht Group, Barberton Greenstone Belt (southern Africa): Evidence for a stable and potentially reversing geomagnetic field at ca. 3.5 Ga: Earth and Planetary Science Letters, v. 302, pp. 314-328.

Campbell, S., and Wood, M., 2002, Scientific vandalism?: Earth Heritage, v. 17 , pp. 3.

Carreras, J., and Druguet, E., 2000, Geological heritage, an essential part of the integral management of World heritage in protected sites, in Barettino D., Wimbledon W.A.P., and Gallego E., eds, Geological Heritage: its conservation and management: Lectures presented in the III International Symposium ProGEO on the Conservation of the Geological Heritage, 1999, Madrid (Spain), pp. 95-110.

Carreras, J., and Gimeno, D., 2000, Geozona 354: Eixam de dics a Aiguablava i Aigua-Xelida: Generalitat de Catalunya, http://www20.gencat.cat/portal/ site/mediambient/menuitem.64be942b6641a1214e9cac3bb0c0e1a0/ ?vgnextchannel=118c1a22693d7210VgnVCM1000008d0c1e0aRCRD\& vgnextfmt=default\&vgnextoid=118c1a22693d7210VgnVCM1000008d 0c1e0aRCRD
Davatzes, N. C., Eichhubl, P., and Aydin, A., 2005, Structural evolution of fault zones in sandstone by multiple deformation mechanisms: Moab fault, southeast Utah: Geological Society of America Bulletin, v. 117, pp. $135-148$.

de Wit, M.J., 2005, Geoheritage research: Geobulletin of the Geological Society of South Africa, March issue, pp. 4-11.

Dudley, N., (ed), 2008, Guidelines for Applying Protected Area Management Categories: Gland, Switzerland: IUCN Publications Services, 86 pp. http:/ /data.iucn.org/dbtw-wpd/html/paps-016/cover.html

Enrique, P., 2009, Las espesartitas, camptonitas y bostonitas del complejo intrusivo de Aiguablava (Cadenas Costeras Catalanas): cartografía y composición: Geogaceta, v. 47, pp. 125-128.

Ferrero, E., Giardino, M., Lozar, F., Giordano, E., Belluso, E., and Perotti, L., 2012, Geodiversity action plans for the enhancement of geoheritage in the Piemonte region (north-western Italy): Annals of Geophysics, v. 55, pp. 487-495.

Fossen, H., 2010, Structural Geology: Cambridge University Press, 463 pp. Gimeno, D., 2002, Estructura y mecanismos intrusivos de los lamprófidos de Sa Planassa - Punta d'Es Mut (Costa Brava, Cordillera Litoral Catalana): su interés didáctico: Treballs del Museu de Geologia de Barcelona, v. 11, pp. 105-133.

Global Geoparks Network, 2010, Guidelines and Criteria for National Geoparks seeking UNESCO's assistance to join the Global Geoparks Network (GGN): UNESCO, 12 pp.

International Declaration on Geoethics, 2011: AGID Working Group for Geoethics, Pribram, Czech Republic, October 2011. http://tierra.rediris.es/ Geoethics_Planetary_Protection/AGID_Geoethics_International_ Declaration.htm

Kerrich, R., Fyfe, W.S., Gorman, B.E., and Allison, I., 1977, Local modification of rock chemistry by deformation: Contributions to Mineralogy and Petrology, v. 65, pp. 183-190.

Kiernan, K., 1997, Landform classification for geoconservation, in Eberhard, R., eds, Pattern and Process: Towards a Regional Approach to National Estate Assessment of Geodiversity, Technical Series No. 2, Australian Heritage Commission \& Environment Forest Taskforce, Environment Australia, Canberra, pp. 21-34.

MacFadyen, C.C.J., 2006, When coring equates to geovandalism: Earth Heritage, v. 27, pp. 12-13.

MacFadyen, C.C.J., 2007, Coreholes: a widespread problem: Earth Heritage, v. 28 , pp. 17.

MacFadyen, C.C.J., 2010, The vandalizing effects of irresponsible core sampling: a call for a new code of conduct: Geology Today, v. 26, pp. 146-151.

MacFadyen, C.C.J., 2011, Irresponsible coring: new guidelines and establishing a methodology for outcrop restoration: Earth Heritage, v. 36, pp. 11-12.

Martel, S.J., Pollard, D.D., and Segall, P., 1988, Development of simple strike slip fault zones, Mount Abbot quadrangle, Sierra Nevada, California: Geological Society of America Bulletin, v. 100, pp. 1451-1465.

Martínez-Frías, J., 2008, Geoethics: Proposal of a geosciences-oriented formal definition and future planetary perspectives, TIERRA: Spanish Thematic Network of Earth and Planetary Sciences (http://tierra.rediris.es), RedIris. documentos, 2008, 1.

Martínez-Frías, J., González, J.L., and Rull-Pérez, F., 2011, Geoethics and Deontology: From fundamentals to applications in Planetary Protection: Episodes, v. 34, pp. 257-262.

Martínez-Poza, A.I., Druguet, E., Castaño, L.M., and Carreras, J., 2012, The Aiguablava dyke swarm from a Structural point of view: Geotemas v. 13 , pp. 153.

Merle, O., Cobbold, P.R., and Schmid S., 1989, Tertiary kinematics in the Lepontine dome: Geological Society, London, Special Publications, v. 45 , pp. 113-134.

Passchier, C.W., 2001, Flanking structures: Journal of Structural Geology, v. 23, pp. 951-962.

Passchier, C.W., 2007, Photograph of the Month: Journal of Structural Geology, v. 29, pp. 1871. 
Passchier, C.W., and Coelho, S., 2006, An outline of shear sense analysis in high-grade rocks: Gondwana Research, v. 10, pp. 66-76.

Pennacchioni, G., and Zucchi, E., in press, High temperature fracturing and ductile deformation during cooling of a pluton: The Lake Edison granodiorite (Sierra Nevada batholith, California). Journal of Structural Geology, doi:10.1016/j.jsg.2012.06.001

Peppoloni, S., and Di Capua, G., 2012, Geoethics and geological culture: awareness, responsibility and challenges: Annals of Geophysics, v. 55, pp. 335-341.

Ramsay, J.G., 1980, Shear zone geometry: a review: Journal of Structural Geology, v. 2, pp. 83-99.

Ramsay, J.G., and Allison, I., 1979, Structural analysis of shear zones in an alpinised Hercynian granite (Maggia Lappen, Pennine Zone, Central Alps): Schweizerische Mineralogische und Petrographische Mitteilungen, v. 59 , pp. 251-279.

Reimold, W.U., Anhaeusser, C.R., Eriksson, K.A., Hofmann, A., Gibson, R.L., Koeberl, Ch., Simonson, B.M., and Westall, F., 2004, Field Forum Report: Processes on the Early Earth, July 4-9, 2004, Kaapvaal Craton, South Africa: GSA Today, v. 14, pp. 28-29.

Reimold, W.U., Whitfield, G., and Wallmach, T., 2006, Geotourism potential of southern Africa, in Dowling, R.K., and Newsome, D., eds, Geotourism, sustainability, impacts and management, Elsevier, pp. 42-62.

Robinson, J.E., 1989a, A Code of Conduct for Rock Coring: Geologists' Asso-

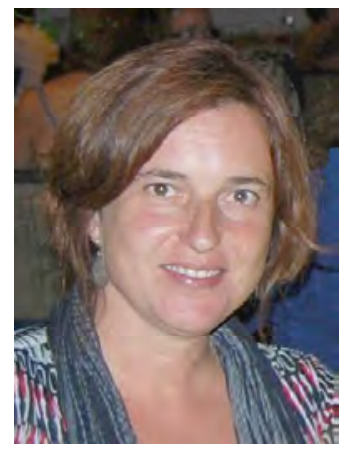

Elena Druguet is an Associate Professor at the Universitat Autònoma de Barcelona, Spain. She is a structural geologist working on the analysis of tectonic structures and the relationships between deformation, metamorphic and magmatic processes. She was member of ProGeo (European Association for the Conservation of the Geological Heritage) and since 2005 is committee member of TecTask (IUGS Commission on Tectonics and Structural Geology), being involved in several projects and publications on geological heritage and geoconservation.

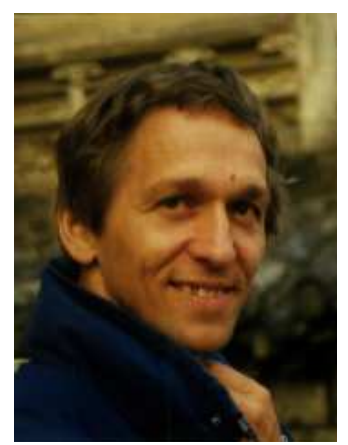

Cees Passchier is a Full Professor in Tectonophysics at the University of Mainz, Germany. His main focus is on the interpretation of small scale deformation structures in metamorphic rocks, with emphasis on ductile shear zones, vein systems and Precambrian geology. His current projects are in Namibia, Egypt, Saudi Arabia, Algeria and Turkey. He is currently Chief Editor of the Journal of Structural Geology. He is also committee member of TecTask and was chairman of this Commission until September 2012. ciation and Conservation Committee of the Geological Society of London. Robinson, E., 1989b, For Geologists: A Code of Conduct for Rock-coring: Environmental Conservation, v. 16, pp. 370-371.

Segall, P., and Pollard, D.D., 1983, Nucleation and growth of strike slip faults in granite: Journal of Geophysical Research, v. 88, pp. 555-568.

Segall, P., and Simpson, C., 1986, Nucleation of ductile shear zones on dilatants fractures: Geology, v. 14, pp. 56-59.

Sharples, C., 2002, Concepts and principles of geoconservation: Tasmanian Parks \& Wildlife Service, Hobart.

Simpson, C., 1981, Ductile shear zones: a mechanism of rock deformation in the orthogneisses of the Maggia Nappe, Ticino: Unpublished Ph.D. thesis, ETH-Zürich.

Simpson, C., 1983, Strain and shape-fabric variations associated with ductile shear zones: Journal of Structural Geology, v. 5, pp. 61-72.

Stürm, B., 2005, Geoconservation in Switzerland - General situation 2005. - GEOforumCH of the Swiss Academy of Sciences, Working Group Geotope, $7 \mathrm{p}$.

UNESCO, 1956, Recommendation on International Principles Applicable to Archaeological Excavations, New Delhi Recommendation. http:// portal.unesco.org/en/ev.php-URL_ID $=13062 \&$ URL_DO $=$ DO_TOPIC\&URL_SECTION=201.html

van Loon, A.J., 2008, Geological education of the future: Earth-Science Reviews, v. 86, pp. 247-254

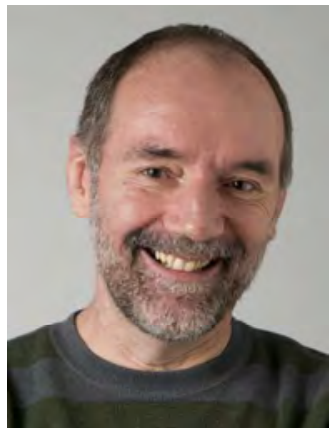

Giorgio Pennacchioni is an Associate Professor at the Department of Geosciences of the Padua University, Italy. He is a structural geologist and his recent research has been mainly focussed on ductile shear zones, microstructures and textures in mylonitic rocks, and exhumed pseudotachylytebearing ("paleoseismic") faults. He is member of the TecTask (IUGS) committee.

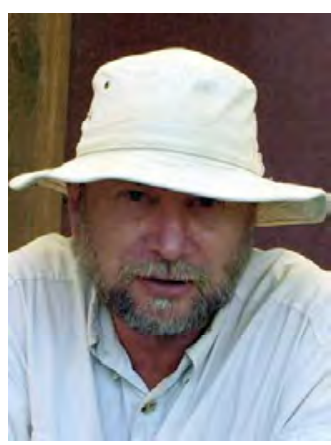

Jordi Carreras is a Professor of structural geology at the Geology department in the Universitat Autònoma de Barcelona, Spain. He has specialised in shear zones and related structures. He is also concerned with Geoconservation and has several publications on this issue. He was Director of the Inventory of Sites of Geological Interest in Catalonia. 